\title{
DISTRIBUSI DAN KELIMPAHAN PENYAKIT KARANG SABUK HITAM SECARA SPASIAL DI KEPULAUAN SERIBU, JAKARTA
}

\author{
Ofri Johan*), Dietriech G. Bengen ${ }^{* *}$, Neviaty P. Zamani**), dan Suharsono ${ }^{* * *}$ \\ *) Pusat Penelitian dan Pengembangan Perikanan Budidaya \\ Jl. Ragunan 20, Pasar Minggu, Jakarta Selatan 12540 \\ E- mail: ofrijohan@kkp.go.id \\ **) Fakultas Perikanan dan IImu Kelautan, Institut Pertanian Bogor \\ JI. Rasamala, Kampus IPB Darmaga, Bogor 16680 \\ ${ }^{* * *}$ Pusat Penelitian dan Pengembangan Oseanologi - LIPI \\ Jl. Pasir Putih Raya 1, Ancol, Jakarta Utara
}

(Naskah diterima: 26 Juni 2012; Disetujui publikasi: 18 Oktober 2013)

\begin{abstract}
ABSTRAK
Penelitian tentang kelimpahan dan penyebaran penyakit karang telah dilaksanakan sejak Juni 2011 sampai Juli 2011 untuk mengetahui kelimpahan awal penyakit karang jenis Black Band Disease (BBD- Penyakit sabuk hitam) di perairan Kepulauan Seribu, Jakarta. Metode pengamatan menggunakan transek sabuk dengan lebar $1 \mathrm{~m}$ ke kiri dan ke kanan, panjang bentangan meteran $20 \mathrm{~m}$ dengan ulangan sebanyak tiga kali. Transek ditempatkan pada dataran terumbu dengan kedalaman 0- $3 \mathrm{~m}$ dengan mencatat jumlah koloni yang terinfeksi penyakit karang, jenis penyakit karang BBD. Hasil penelitian menunjukkan bahwa penyakit karang jenis BBD banyak ditemukan pada tutupan karang yang tinggi dan karang jenis Montipora sp. dominan di lokasi tersebut. Berdasarkan lokasi secara umum kelimpahan tertinggi terjadi di Pulau Pramuka Utara $(0,15 \mathrm{kol} / \mathrm{m})$; Pulau Pari Timur $(0,092 \mathrm{kol} / \mathrm{m})$; Pulau Penjaliran $(0,092 \mathrm{kol} / \mathrm{m})$; dan Pulau Tikus $(0,085 \mathrm{kol} / \mathrm{m})$. Hasil uji statistik dengan menggunakan ANOVA diperoleh kelimpahan penyakit karang BBD berbeda nyata antara kelompok lokasi penelitian, yaitu antara lokasi jarak terdekat dengan jarak sedang, dan lokasi jarak terdekat dengan jarak terjauh dengan nilai perbedaan (signifikan) berturut- turut 0,030 dan 0,025 (tingkat kepercayaan 95\%). Sedangkan pada kelompok lokasi jarak sedang dan terjauh tidak terdapat perbedaan nyata. Berdasarkan data klimatologi, peningkatan suhu pada bulan Maret hingga Juli dapat memicu terjadi penyakit karang di kawasan Kepulauan Seribu.
\end{abstract}

KATA KUNCI: kelimpahan, penyakit sabuk hitam, Montipora sp., Kepulauan Seribu

ABSTRACT: Distribution and abundant of black band disease on corals in Seribu Island, Jakarta. By: Ofri Johan, Dietriech G. Bengen, Neviaty P. Zamani, and Suharsono

Research on the abundance and distribution of coral has been implemented since June and July 2011 to determine the prelimanary abundance of coral disease on several islands in the Seribu Island, Jakarta. Observation method was used a belt transect with a width of $1 \mathrm{~m}$ to the left and right, $20 \mathrm{~m}$ long stretch of the meter tape with the test three times. Transects placed on the reef plate with a depth of 0-3 m with a record number of infected colonies of BBD. The results show that coral diseases types of BBD found in many on the high coral cover and on coral species Montipora sp. dominant at that location. Based on the general location, the highest abundance found at Northern of Pramuka Island $(0.15 \mathrm{col} / \mathrm{m})$, East of Pari Island $(0.092 \mathrm{col} / \mathrm{m})$, 
Penjaliran Island $(0.092 \mathrm{col} / \mathrm{m})$, and Tikus Island $(0.085 \mathrm{col} / \mathrm{m})$. Statistical test by using ANOVA obtained results that BBD abundance of coral disease was significantly different between groups of study sites, namely the distance between the closest sites and the middle sites, and between the nearest sites and the farthest distance from the mainland of Java Island with the value of the difference (significant) respectively are 0.030 and 0.025 (confidence level 95\%). While the sites between the middle sites and the furthest distance being no real difference. Based on climatological data, the increase in temperature in March and July could lead to coral diseases that occured in the Seribu Island region.

\section{KEYWORDS: abundance, black band disease, Montipora sp., Seribu Island}

\section{PENDAHULUAN}

Kepulauan Seribu terdiri atas 105 gugus pulau terbentang vertikal dari Teluk Jakarta hingga ke Utara dengan Pulau Sebira sebagai pulau terluar dengan jarak kurang lebih 150 km dari pantai Jakarta Utara. Sebagian dari jumlah pulau tersebut terdapat 11 pulau yang berpenduduk yaitu Pulau Panggang, Pulau Pramuka, Pulau Kelapa, Pulau Kelapa Dua, Pulau Harapan, Sebira, Pulau Tidung Besar, Pulau Payung, Pulau Pari, Pulau Lancang Besar, dan Pulau Untung Jawa.

Secara geografis Kepulauan Seribu berada antara $106^{\circ} 20^{\prime} 00^{\prime \prime}$ BT hingga $106^{\circ} 57^{\prime} 00^{\prime \prime}$ dan $5^{\circ} 10^{\prime} 00^{\prime \prime}$ LS hingga $5^{\circ} 57^{\prime} 00^{\prime \prime}$ LS. Wilayah administrasi Kabupaten Kepulauan Seribu memiliki luas daratan mencapai 897,71 ha dan luas perairan mencapai $6.997,50 \mathrm{~km}^{2}$.

Kawasan terumbu karang Kepulauan Seribu merupakan daerah yang dekat dengan kota besar yaitu ibu kota negara yang memiliki jumlah penduduk yang sangat padat sebanyak 9,604 juta jiwa, jumlah penduduk di Kepulauan Seribu itu ada sebanyak 21,082 ribu jiwa (BPS DKI Jakarta, 2010). Pembangunan kota yang terus berkembang dan aktivitas penduduk yang padat inilah yang membuat terjadinya salah satu polusi antropogenik dari daratan hingga ke Kepulauan Seribu terutama di Teluk Jakarta. Kondisi ini terlihat jelas pada musim Timur di mana banyak sampah terbawa ke pulau dan warna perairan agak keruh. Salah satu indikasi lain yang dirasakan oleh penduduk adalah rumput laut tidak bisa tumbuh baik di Pulau Pari, kondisi tersebut diduga karena sudah menurunnya kualitas perairan di daerah tersebut.

Faktor lain yang perlu dicermati adalah pengaruh dampak perubahan iklim dengan adanya fluktuasi suhu dan tinggi muka air laut, kondisi tersebut dapat juga memengaruhi kelangsungan biota yang ada di laut, termasuk biota yang berasosiasi dengan ekosistem terumbu karang. Pemanasan global dapat meningkatkan suhu air laut sehingga terumbu karang akan mengalami stres dan apabila gangguan ini berjalan terus dapat menyebabkan terjadinya pemutihan karang (bleaching) dan kematian massal. Kematian pada karang yang selama ini sebagai habitat bagi berbagai biota yang berasosiasi dengannya, akan mulai terganggu dan pada akhirnya akan berdampak pada produksi perikanan yang berasal dari ekosistem terumbu karang, sementara sebagian besar masyarakat pesisir tergantung terhadap ekosistem tersebut sebagai sumber mata pencaharian.

Salah satu akibat dari kondisi lingkungan yang tidak mendukung adalah fluktuasi suhu, keadaan ini akan memberikan dampak negatif bagi kehidupan karang yaitu timbulnya penyakit karang. Di samping itu, penyakit karang juga dapat disebabkan oleh adanya polusi antropogenik dan juga tingginya intensitas penyinaran cahaya matahari di perairan yang memiliki terumbu karang.

Polusi antropogenik merupakan suatu bentuk cemaran yang diakibatkan oleh aktivitas manusia seperti adanya limbah rumah tangga dan pabrik yang terbawa oleh aliran sungai sampai ke laut. Di Teluk Jakarta tingkat sedimentasi dan limbah antropogenik ini cukup tinggi hingga terbawa arus sampai ke pulau- pulau lain di Kepulauan Seribu.

Sebagai gambaran kondisi terumbu karang di Kepulauan Seribu dapat dilihat dari hasil penelitian yang dilakukan oleh Yayasan Terangi dalam kurun waktu 2005- 2009 pada 19 lokasi di Kepulauan Seribu, kondisi terumbu karang dari tutupan karang keras mengalami fluktuasi yaitu dalam selang antara $28,9 \%$ hingga 34,3\%(Setyawan et al., 2011), berarti masih berada pada kelompok kondisi sedang 
(Gomez \&Yap, 1984). Secara keseluruhan total marga yang ditemukan di Kepulauan Seribu sebanyak 63 marga dari hasil pengamatan sejak tahun 2005- 2009 (Setyawan et al., 2011).

Pengamatan tentang kelimpahan penyakit karang sabuk hitam atau black band disease (BBD) telah dilakukan pada penelitian ini terhadap Montipora sp. dan telah dikaji kaitannya dengan faktor penyebab munculnya penyakit karang tersebut. Penyakit black band disease (BBD) diterjemahkan menjadi penyakit sabuk hitam adalah salah satu penyakit karang tertua, pertama kali ditemukan yang disebabkan oleh gabungan mikroba pathogen yang secara bersama- sama membentuk sabuk di mana bentuk gabungan tersebut terdiri atas lima macam; berupa bakteri berbentuk filamen dari kelompok cyanobacterium Phormidium corallyticum, bakteri kelompok heterotropik (Garrett \& Ducklow 1975), jamur laut (RamosFlores, 1983), bakteri pengoksidasi sulphid (Beggiota) dan bakteri yang menurunkan sulphat (Desulfovibrio) (Ducklow \& Mitchell, 1979; Richardson, 1996). Populasi cyanobacteria dicirikan dengan adanya warna hitam kecoklatan hingga merah, tebal sabuknya 1 mm dengan lebar antara 1- $3 \mathrm{~mm}$.

Penyakit karang sabuk hitam sudah pernah ditemukan pada Montipora sp. yang bentuk pertumbuhan mengerak (encrusting), lembaran daun (foliose), dan bercabang (branching). Penyakit sabuk hitam pertama kali ditemukan pada perairan terumbu karang di Belize, Puerto Rico, Florida, dan Bermuda (Antonius, 1973), saat ini sudah terjadi pada 36 negara termasuk wilayah Indo- Pacific, namun penelitian tentang penyakit sabuk hitam ini baru pertama kali dilakukan di Kepulauan Seribu, Indonesia.

Tujuan penelitian ini adalah untuk mengkaji penyebaran dan kelimpahan penyakit karang, mengenali jenis penyakit karang dan parameter kesehatan karang lainnya.

\section{METODE PENELITIAN}

\section{Lokasi Penelitian}

Penelitian dimulai sejak Juni sampai Juli 2011 di beberapa pulau di Kepulauan Seribu Jakarta, meliputi: Pulau Pari, Pulau Tikus, Pulau Pramuka, Pulau Semak Daun, Pulau Kelapa, Pulau Kotok, Pulau Putri, Pulau Belanda, dan Pulau Peteloran seperti terlihat pada Tabel 1. Lokasi menyebar dari Selatan hingga ke Utara atau lokasi yang dekat sampai terjauh dari daratan utama (Pulau Jawa), di antaranya men-

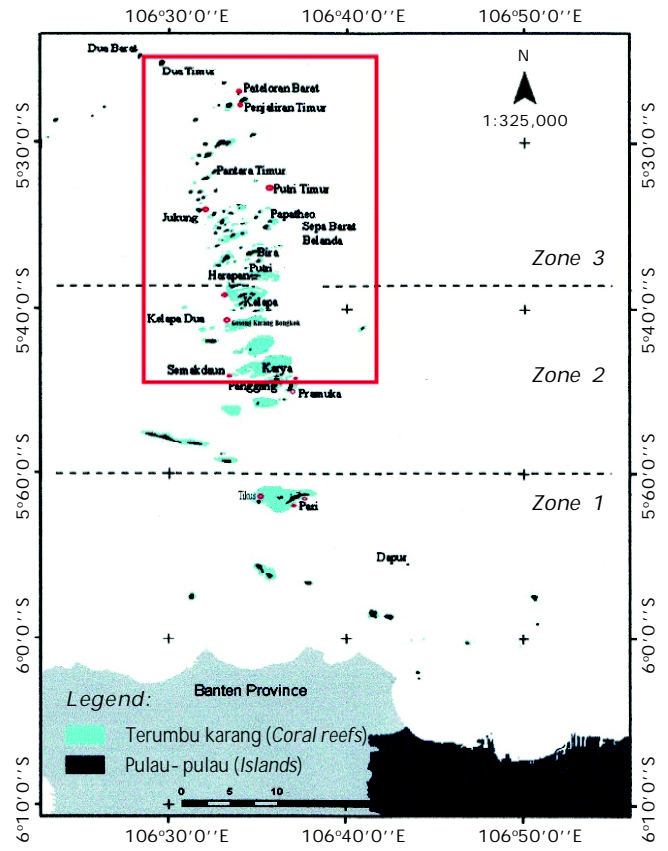

Gambar 1. Lokasi penelitian mewakili terdekat (Zona 1), sedang (Zona 2) dan terjauh (Zona 3) dari daratan utama (Estradivari et al., 2009, Farhan \& Lim, 2012). Garis merah segi empat merupakan kawasan Taman Nasional

Figure 1. Research sites located the nearest (Zone 1 ), middle (Zone 2), and the farthest (Zone 3) from the mainland (Estradivari et al., 2009, Farhan \& Lim, 2012). Redline square is Marine National Park area

cakup zona inti Taman Nasional Laut Kepulauan Seribu Jakarta dan beberapa di antara pulau- pulau tersebut merupakan pulau yang berpenduduk. Pulau yang berada di zona inti yang tidak ada penduduknya diasumsikan daerah tersebut jauh dari sumber polusi antropogenik baik yang berasal dari pulau tersebut maupun yang terbawa dari pulau utama dan pulau lainnya.

\section{Pengumpulan Data}

\section{Data Kondisi Terumbu Karang}

Pengambilan data kondisi terumbu karang dilakukan dengan menggunakan metode transek garis (Line Intercept Transect) pada kedalaman antara 1- $3 \mathrm{~m}$ (reef flat) dan 3- $7 \mathrm{~m}$ 
Tabel 1. Lokasi penelitian

Table 1. Research locations

\begin{tabular}{|c|c|c|c|}
\hline $\begin{array}{l}\text { Lokasi penelitian } \\
\text { Research location }\end{array}$ & $\begin{array}{l}\text { Lintang } \\
\text { Latitute }\end{array}$ & $\begin{array}{l}\text { Bujur } \\
\text { Longitute }\end{array}$ & $\begin{array}{l}\text { Kedalaman } \\
\text { Depth (m) }\end{array}$ \\
\hline \multicolumn{4}{|c|}{$\begin{array}{l}\text { Lokasi tidak berpenduduk (Jarak terjauh dari Pulau Jawa) } \\
\text { Unpopulated location (The farthest distance from Java Island) }\end{array}$} \\
\hline - Pulau Peteloran (Peteloran Island) & $05^{\circ} 27^{\prime} 07.6^{\prime \prime}$ & $106^{\circ} 33^{\prime} 44.9^{\prime \prime}$ & 1.5 \\
\hline - Pulau Penjaliran (Penjaliran Island ) & $05^{\circ} 27^{\prime} 34.0^{\prime \prime}$ & $106^{\circ} 33^{\prime} 49.3^{\prime \prime}$ & 1.5 \\
\hline - Utara Pulau Jukung (North of J ukung Island ) & $05^{\circ} 34^{\prime} 00.1^{\prime \prime}$ & $106^{\circ} 31^{\prime} 36.3^{\prime \prime}$ & 7.0 \\
\hline - Utara Pulau Putri (North of Putri Island ) & $05^{\circ} 35^{\prime} 25.5^{\prime \prime}$ & $106^{\circ} 34^{\prime} 03.6^{\prime \prime}$ & 6.0 \\
\hline - Barat Pulau Belanda (West of Belanda Island) & $05^{\circ} 36^{\prime} 16.4^{\prime \prime}$ & $106^{\circ} 31^{\prime} 08.4^{\prime \prime}$ & 7.0 \\
\hline \multicolumn{4}{|c|}{$\begin{array}{l}\text { Lokasi berpenduduk } 1 \text { (Jarak sedang dari Pulau Jawa) } \\
\text { Inhabited location } 1 \text { (The middle distance from from Java Island) }\end{array}$} \\
\hline - Selatan Pulau Pramuka (South of Pramuka Island) & $05^{\circ} 45^{\prime} 01.9^{\prime \prime}$ & $106^{\circ} 36^{\prime} 41.5^{\prime \prime}$ & 1.5 \\
\hline - Utara Pulau Pramuka (North of Pramuka Island) & $05^{\circ} 44^{\prime} 24.9^{\prime \prime}$ & $106^{\circ} 37^{\prime} 14.5^{\prime \prime}$ & 1.5 \\
\hline - Gosong Karang Bongkok & - & - & 3.0 \\
\hline - Selatan Pulau Kelapa (South of Kelapa Island ) & - & - & 6.0 \\
\hline - Pulau Semak Daun (Semak Daun Island) & $05^{\circ} 43^{\prime} 37.0^{\prime \prime}$ & $106^{\circ} 33^{\prime} 59.2^{\prime \prime}$ & 6.0 \\
\hline \multicolumn{4}{|c|}{$\begin{array}{l}\text { Lokasi berpenduduk } 2 \text { (Jarak terdekat dari Pulau Jawa) } \\
\text { Inhabited location } 2 \text { (The nearest distance from Java Island) }\end{array}$} \\
\hline - Selatan Pulau Pari 1 (South of Pari 1 Island ) & $05^{\circ} 52^{\prime} 14.0^{\prime \prime}$ & $106^{\circ} 36^{\prime} 38.8^{\prime \prime}$ & 1.5 \\
\hline - Selatan Pulau Pari 2 (South of Pari 2 Island) & $05^{\circ} 51^{\prime} 65.1^{\prime \prime}$ & $106^{\circ} 37^{\prime} 25.0^{\prime}$ & 1.5 \\
\hline - Utara Pulau Tikus (North of Tikus Island) & $05^{\circ} 51^{\prime} 07.8^{\prime \prime}$ & $106^{\circ} 34^{\prime} 53.8^{\prime \prime}$ & 6.0 \\
\hline
\end{tabular}

(reef slope) sebanyak tiga ulangan dengan panjang transek $20 \mathrm{~m}$. Pada teknik Line Intercept Transect (LIT), life form dan substrat pada titik random dianalisis dengan menggunakan sistem klasifikasi dengan persamaan menurut English et al. (1997) sebagai berikut:

$$
\mathrm{Li}=\frac{\mathrm{ni}}{\mathrm{L}} \times 100 \%
$$

di mana:

$\mathrm{Li}=$ Persentase penutupan biota karang ke- $\mathrm{i}$

$\mathrm{ni}=$ Panjang total kelompok biota karang ke- $\mathrm{i}$

$\mathrm{L}=$ Panjang total transek garis

Hasil tutupan karang hidup yang tinggi menunjukkan bahwa kondisi terumbu karang di lokasi tersebut berada dalam kondisi yang baik.

\section{Data Kelimpahan Penyakit Karang}

Pengambilan data menggunakan transek sabuk (belt transect) dengan lebar masingmasing $1 \mathrm{~m}$ ke samping kiri dan samping kanan garis transek dengan panjang transek $20 \mathrm{~m}$ sebanyak tiga ulangan, sehingga luas cakupan daerah $120 \mathrm{~m}^{2}$. Data yang diambil di lapangan adalah kelimpahan penyakit karang terutama jenis black band disease (BBD) dan white syndrom (WS) serta jenis lain yang termasuk dalam parameter kesehatan karang (Raymundo et al., 2008). Tutupan karang pada lokasi diukur dengan menggunakan metode LIT (Line Intercept Transect) dengan panjang $20 \mathrm{~m}$ sebanyak tiga kali ulangan. Identifikasi jenis penyakit karang dilakukan berdasarkan buku panduan Raymundo et al. (2008) dan Beeden et al. (2008).

\section{Data Kualitas Perairan}

Parameter lingkungan yang diukur meliputi oseanografi fisik (kedalaman, suhu air, kecerahan, intensitas cahaya, dan substrat dasar), dan kimia (DO, pH, nitrat, dan ortofosfat). Pengukuran data in situ dengan menggunakan alat YSI 556 MPS, sementara parameter lain dilakukan pengambilan sampel dan dianalisis 
di Laboratorium Pengujian Produktivitas dan Lingkungan Perairan (Proling), Departemen Manajemen Sumberdaya Perairan- IPB.

Sebagai perbandingan data suhu untuk melihat dampak pemanasan global dengan menggunakan data dari Cor al Reef Watch satellite (SST) Sea Surface Temperature anomaly yang dikeluarkan oleh National Oceanographic and Atmospheric Administration (NOAA) pada tahun 2009, 2010, dan 2011. http:// coralreefwatch.noaa.gov.

Data kualitas perairan akan dianalisis dengan menggunakan Diskriminan Analisis menggunakan software komputer program SPSS, untuk mendapatkan perbedaan antar lokasi yang dicirikan oleh parameter kualitas perairan yang dominan.

\section{Bahan dan Alat Penelitian}

Penelitian ini menggunakan alat dasar lengkap snorkeling (fins, masker, wetsuit), rol meter, kamera underwater merek Cannon Ixus 120 , alat pengukur kualitas air in situ merk YS 556 MPS (suhu, konduktivitas, TDS, salinitas, $\mathrm{DO}, \mathrm{pH})$, secchi disk, pengukur kecepatan arus, alat tulis bawah air, dan skala standar untuk pengambilan foto bawah air.

\section{Analisis Data}

Analisis statistik untuk membandingkan antara lokasi dengan menggunakan uji ANOVA terhadap kelimpahan penyakit karang dalam satuan luas yang diamati $\left(120 \mathrm{~m}^{2}\right)$. Hubungan antara tutupan karang hidup dengan tutupan karang jenis Montipora sp. di lokasi ditemukan BBD (black band disease) dilakukan uji statistik dengan regresi. Kondisi parameter kualitas perairan digunakan metode diskriminan analisis untuk melihat pembeda antara kelompok lokasi penelitian.

\section{HASIL DAN BAHASAN}

\section{Hasil Penelitian}

\section{Kondisi Terumbu Karang}

Secara keseluruhan tutupan karang hidup ditemukan cukup tinggi pada lokasi keberadaan penyakit karang BBD (black band disease) yaitu berkisar antara 57,17\% 76,88\% tutupan seperti ini dikelompokkan padakondisi karang baik dan sangat baik menurut kategori Gomez \& Yap (1984). Tutupan karang tersebut didominasi oleh bentuk pertumbuhan CF (coral foliose) dari jenis karang Montipora sp. berkisar antara 32,08\% 57,75\% sementara sisanya merupakan karang mati, alga, biota lain dan abiotik. Tutupan karang hidup di lokasi terjauh, Pulau Peteloran, lebih tinggi $(76,88 \%$ dibandingkan dengan Pulau Pari $(71,79 \%$ dan terendah pada Pulau Pramuka $(57,17 \%$.

Hasil uji statistik dengan menggunakan ANOVA tidak terdapat perbedaan antara

Tabel 2. Parameter fisik-kimia air yang diukur harian dan bulanan

Table 2. Physics and chemist parameters measured daily and monthly

\begin{tabular}{|c|c|}
\hline Parameter (Parameters) & Alat (Tools)/ Metode (Methods) \\
\hline \multicolumn{2}{|l|}{ Fisika perairan (Physic of water) } \\
\hline Suhu (Temperature ) $\left({ }^{\circ} \mathrm{C}\right)$ & Data Logger merk Hobo* \\
\hline TSS (Total suspended solid ) (mg/ L) & TSS meter \\
\hline Intensitas cahaya (Light intensity) & Data Logger merk Hobo* \\
\hline \multicolumn{2}{|l|}{ Kimia perairan (Chemist of water) } \\
\hline Salinitas (Salinity) (\%ф) & Refraktometer \\
\hline Derajat keasaman $(\mathrm{pH})$ & $\mathrm{pH}$ meter \\
\hline Ortofosfat (mg/ L) & Ascorbic acid spectrofotometric \\
\hline Nitrat $\left(\mathrm{NO}_{3}\right)(\mathrm{mg} / \mathrm{L})$ & Brucine spectrofotometric \\
\hline Oksigen terlarut (Dissolved oxygen ) (mg/ L) & DO meter \\
\hline
\end{tabular}




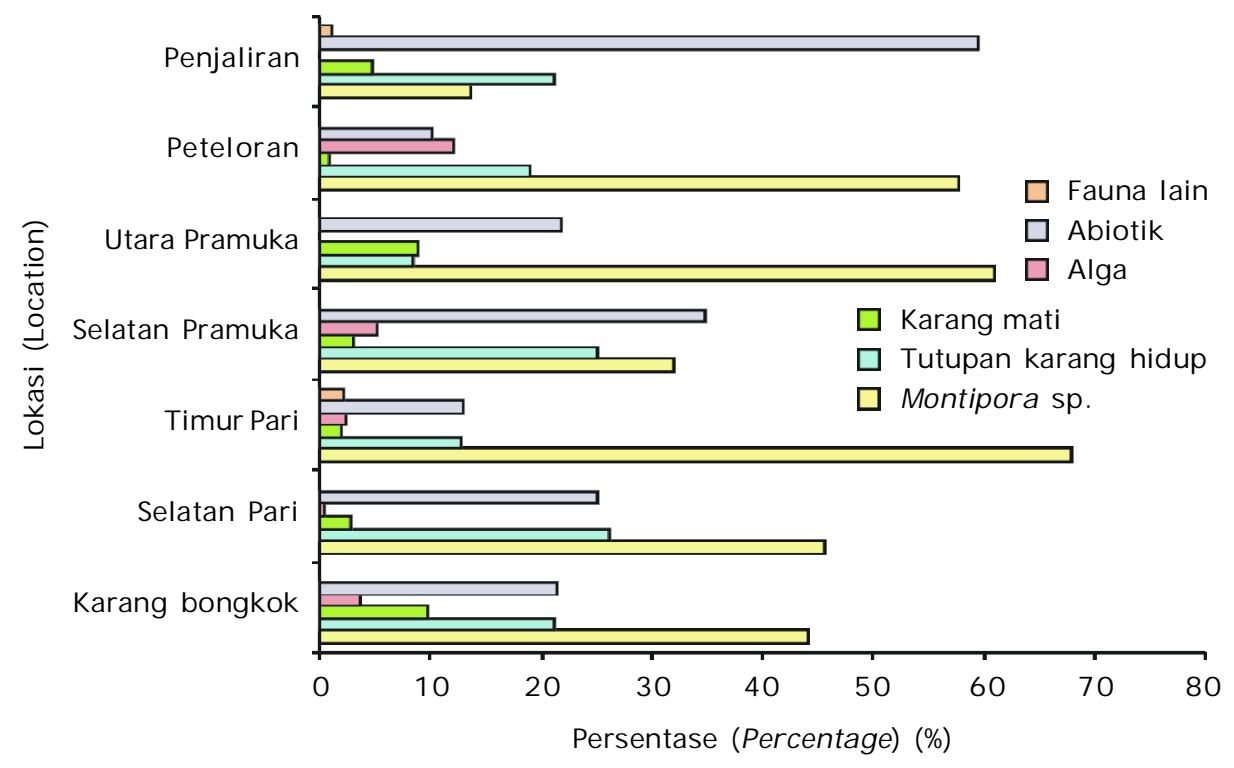

Gambar 2. Persentase tutupan karang hidup (life coral), tutupan Montipora sp. dan tutupan parameter lain berdasarkan data transek garis pada beberapa lokasi di Kepulauan Seribu Jakarta

Figure 2. Percentage of life coral cover, Montipora sp. cover and other biota cover according to line transect on several locations at Seribu Island, Jakarta

tutupan karang hidup dibandingkan antar kelompok lokasi penelitian yaitu antara lokasi jarak terdekat, jarak sedang, dan jarak terjauh dari daratan utama Pulau Jawa. Hal ini dikarenakan sebagian besar penyakit karang ditemukan pada tutupan karang berkondisi baik dan sangat baik di mana pada lokasi tersebut ditemukan banyak karang Montipora sp. Pengujian secara statistik dengan metode regresi antara persentase tutupan karang hidup dan tutupan karang Montipora sp. diperoleh bahwa terdapat hubungan yang kuat di antara kedua parameter tersebut dengan nilai regresi $(R)$ sebesar 0,91 .

\section{Kelimpahan Penyakit Karang}

Lokasi penelitian di mana ditemukan banyak karang terinfeksi penyakit berada pada kedalaman antara 1-2 m di daerah dataran terumbu (reef flats). Sementara pada kedalaman lain antara 3- 7 m (reef crest) dan kedalaman 7- 12 m (reef slope) tidak ditemukan penyakit BBD. Sehingga ditetapkan pengamatan hanya dilakukan pada dataran terumbu saja.

Pada Gambar 3, terlihat bahwa ada beberapa lokasi tempat ditemukannya penyakit karang BBD, kelimpahan tertinggi terjadi di Pulau Pramuka Utara $\left(0,15 \mathrm{kol} . \mathrm{m}^{-2}\right)$; Pulau Pari Timur (0,092 kol. $\left.\mathrm{m}^{-2}\right)$; Pulau Penjaliran $(0,092$ kol. $\left.\mathrm{m}^{-2}\right)$; dan Pulau Tikus $\left(0,085 \mathrm{kol} . \mathrm{m}^{-2}\right)$. Jenis karang yang terinfeksi penyakit hanya terjadi pada karang jenis Montipora sp. dengan bentuk pertumbuhan menyerupai daun (foliose) dan mengerak (encrusting). Sementara pada karang Montipora sp. dengan bentuk pertumbuhan bercabang tidak ditemukan terinfeksi oleh penyakit BBD pada awal penelitian ini tapi pada monitoring berikutnya di lokasi permanen transek pernah ditemukan. Pada jenis karang lain juga belum pernah ditemukan penyakit BBD selama penelitian. Sebagai perbandingan, pada lokasi penelitian juga ditemukan jenis penyakit lain seperti white syndrome (WS) banyak ditemukan pada karang Montipora sp. dengan bentuk pertumbuhan foliose, encrusting dan juga pada jenis karang Acropora sp. Kelimpahan WS tertinggi terjadi pada Pulau Pramuka Selatan $\left(0,11\right.$ kol. $\left.\mathrm{m}^{-2}\right)$; Pulau Kelapa $\left(0,07 \mathrm{kol} . \mathrm{m}^{-2}\right)$; dan Gosong Karang Bongkok $\left(0,05 \mathrm{kol} . \mathrm{m}^{-2}\right)$.

Sementara kondisi yang mengganggu kesehatan karang tapi tidak tergolong penyakit (compromised health) banyak ditemukan 
Distribusi dan kelimpahan penyakit karang sabuk hitam ..... (Ofri Johan)

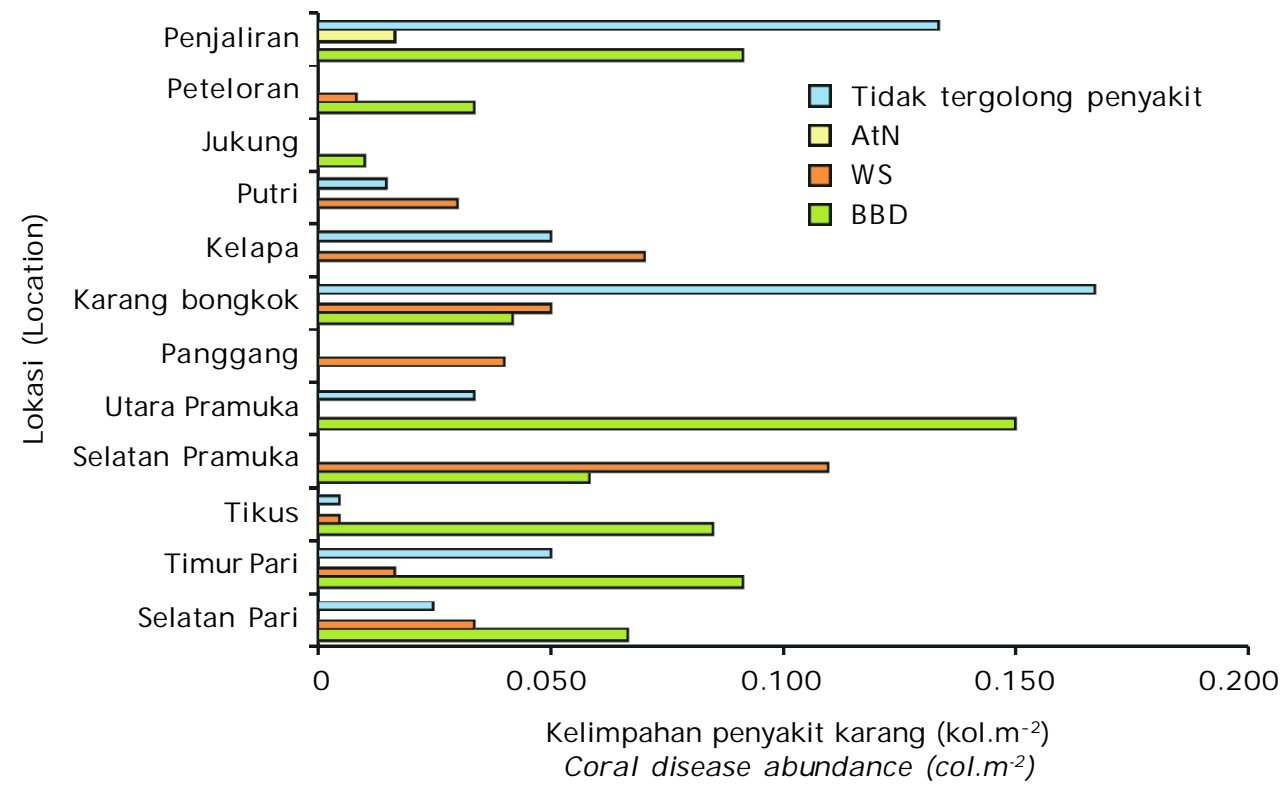

Gambar 3. Perbandingan kelimpahan penyakit BBD dengan penyakit lain pada beberapa lokasi di Kepulauan Seribu

Figure 3. The comparation of BBD abundant and others kind disease on several location at Seribu Island

pada lokasi Gosong Karang Bongkok adalah kompetisi dengan spons dan adanya predator Achantaster plancii dengan nilai sebesar $0,17 \mathrm{kol} . \mathrm{m}^{-2}$ (Gambar 3). Lokasi lain seperti di Pulau Kelapa juga banyak didominasi oleh Achantaster plancii dengan meninggalkan jejak yang memutih pada koloni karang yang dilewatinya.

Keberadaan penyakit karang BBD di Kepulauan Seribu hanya terkonsentrasi pada satu jenis karang saja yaitu Montipora sp., berbeda dengan yang ditemukan oleh beberapa penelitian lainnya yang mengatakan penyakit karang BBD dapat menginfeksi pada beberapa jenis karang dan terdistribusi secara merata (Frias- Lopez et al., 2003).

Hasil uji statistik dengan menggunakan ANOVA diperoleh perbandingan kelimpahan penyakit karang BBD berbeda nyata antara kelompok lokasi penelitian. Di mana pada kelompok lokasi jarak terdekat dengan jarak sedang, dan kelompok lokasi jarak terdekat dengan jarak terjauh terdapat perbedaan nyata kelimpahan penyakit BBD dengan nilai perbedaan (significant) berturut- turut 0,030 dan 0,025 (tingkat kepercayaan 95\%). Sementara kelimpahan pada kelompok lokasi pada jarak sedang dan terjauh tidak terdapat perbedaan nyata secara uji statistik (Gambar 3 dan Tabel 3).

Berdasarkan data rataan harian suhu selama 11 tahun terakhir tercatat suhu maksimum sebesar $32^{\circ} \mathrm{C}$, minimum pada suhu $23^{\circ} \mathrm{C}$, dan rataan harian sebesar $28,5^{\circ} \mathrm{C}$. Pada tahun 2011 saat penelitian berlangsung rataan suhu tahun 2011 diperoleh sebesar rataan $28,44^{\circ} \mathrm{C}$; minimum $23,2^{\circ} \mathrm{C}$; dan maksimum pada suhu $35,4^{\circ} \mathrm{C}$. Berdasarkan grafik suhu pada Gambar 4 terlihat bahwa terjadi peningkatan suhu dari bulan Maret hingga Juli dan kemudian dari bulan September dan Desember dari 4 tahun data yang ditampilkan. Kondisi tersebut dapat memicu terjadinya penyakit karang di kawasan Kepulauan Seribu.

\section{Kondisi Kualitas Perairan}

Pengukuran parameter kualitas perairan secara in situ didapatkan data suhu, salinitas, DO, pH, dan TDS. Berdasarkan data suhu diperoleh selang rataan antara $28,98^{\circ} \mathrm{C}$ $29,39^{\circ} \mathrm{C}$; kondisi tersebut masih berada dalam selang baku mutu (Tabel 4). Penelitian sebelumnya di Pulau Pari diperoleh selang suhu. 

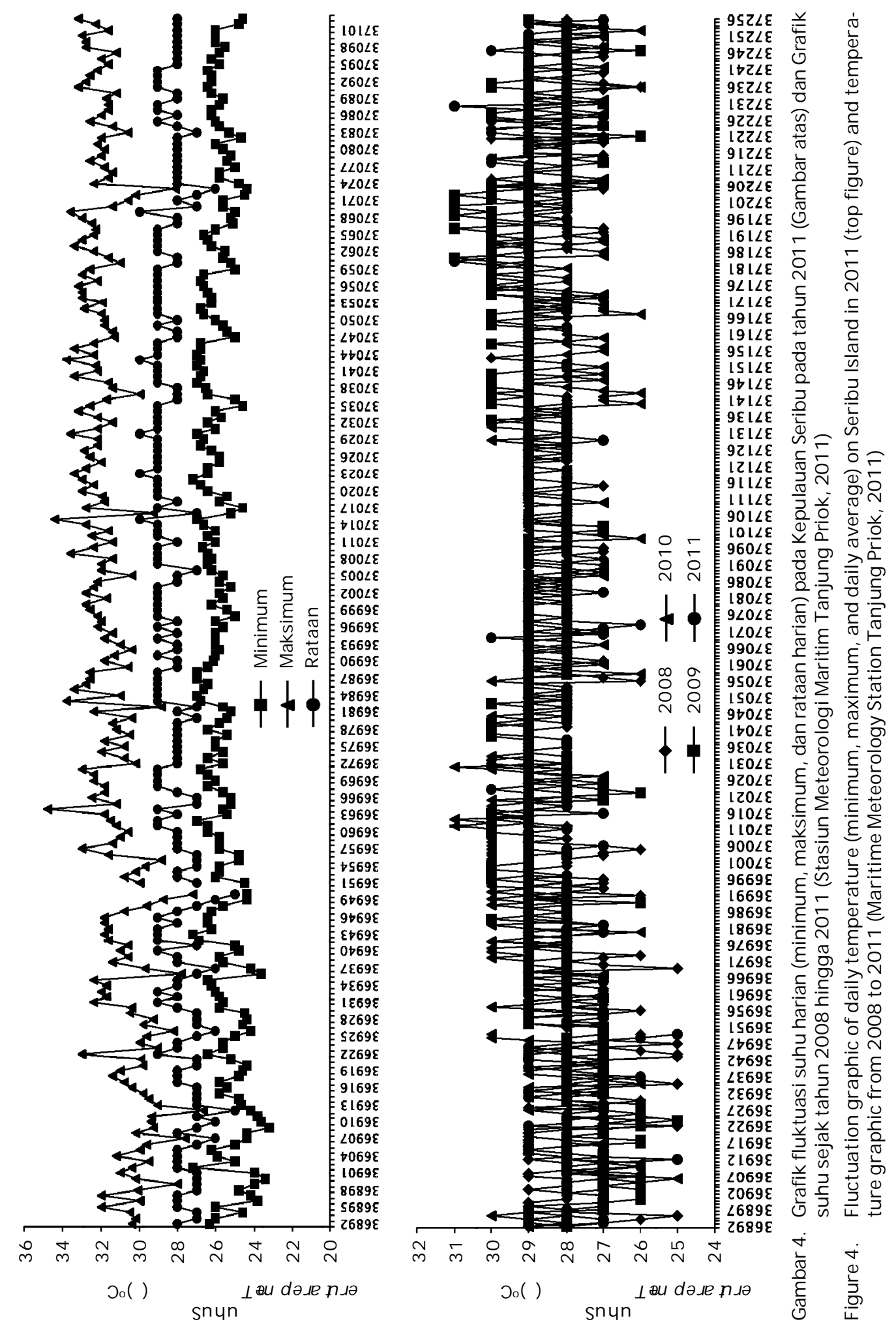
Tabel 3. Uji statistik perbedaan kelimpahan antar kelompok lokasi penelitian

Table3. Statistic test of abundant different between research sites group

\begin{tabular}{|c|c|c|c|c|c|}
\hline $\begin{array}{l}\text { Kelompok lokasi } \\
\text { Location group }\end{array}$ & $\begin{array}{l}\text { Jumlah lokasi } \\
\text { Number of } \\
\text { location } \\
\text { (N) }\end{array}$ & $\begin{array}{l}\text { Rataan } \\
\text { Average }\end{array}$ & $\begin{array}{c}\text { Standar } \\
\text { deviasi } \\
\text { Standard } \\
\text { deviation }\end{array}$ & $\begin{array}{c}\text { Standar } \\
\text { kesalahan } \\
\text { Standard } \\
\text { error }\end{array}$ & Sig. \\
\hline $1=$ Terdekat $(1=$ Nearest $)$ & 3 & 12 & 4.583 & 2.646 & \\
\hline $2=$ Sedang $(2=$ Medium $)$ & 4 & 3 & 3.559 & 1.780 & \\
\hline $3=$ Terjauh $(3=$ Farthest $)$ & 3 & 2 & 2.000 & 1.155 & \\
\hline Lokasi 1*2 (Location 1*2 ) & & 9 & & 2.708 & $0.030 *$ \\
\hline Lokasi 1*3 (Location 1*3 ) & & 10 & & 2.895 & $0.025 *$ \\
\hline Lokasi $2 * 3$ (Location $2 * 3$ ) & & 1 & & 2.708 & 0.928 \\
\hline
\end{tabular}

Tabel 4. Hasil pengukuran parameter kualitas air in situ

Table4. Measurement result of in situ waters quality

\begin{tabular}{|c|c|c|c|c|}
\hline \multirow{2}{*}{$\begin{array}{l}\text { Parameter } \\
\text { Parameters }\end{array}$} & \multicolumn{3}{|c|}{ Lokasi (Location) } & \multirow{2}{*}{$\begin{array}{c}\text { Baku mutu } \\
\text { Quality } \\
\text { standards }\end{array}$} \\
\hline & $\begin{array}{l}\text { Terdekat } \\
\text { Nearest }\end{array}$ & $\begin{array}{l}\text { Sedang } \\
\text { Medium }\end{array}$ & $\begin{array}{l}\text { Terjauh } \\
\text { Farthest }\end{array}$ & \\
\hline Suhu (Temperature ) $\left({ }^{\circ} \mathrm{C}\right)$ & $29.39 \pm 0.70$ & $28.98 \pm 0.86$ & $29.13 \pm 0.79$ & $28-30$ \\
\hline Salinitas (Salinity) (\%ф & $32.02 \pm 4.31$ & $34.99 \pm 0.55$ & $34.79 \pm 0.46$ & $33-34$ \\
\hline $\begin{array}{l}\text { Oksigen terlarut } \\
\text { Dissolved oxygen }(\mathrm{mg} / \mathrm{L})\end{array}$ & $8.31 \pm 1.60$ & $7.28 \pm 2.09$ & $7.78 \pm 1.86$ & $>5$ \\
\hline $\mathrm{pH}$ & $7.53 \pm 0.28$ & $7.54 \pm 0.23$ & $7.28 \pm 0.25$ & $7.0-8.5$ \\
\hline TDS (mg/ L) & $31.93 \pm 3.85$ & $34.6 \pm 0.48$ & $34.43 \pm 0.40$ & - \\
\hline Turbiditas (Turbidity ) & - & - & - & - \\
\hline
\end{tabular}

Berdasarkan hasil uji statistik dengan Analisis Diskriminan untuk melihat perbedaan antar lokasi yang dicirikan oleh parameter kualitas air, diperoleh bahwa peran fungsi sumbu pertama dan kedua berturut-turut adalah $77,6 \%$ dan $22,4 \%$ Keberadaan dua fungsi sumbu tersebut sudah dapat menjelaskan perbedaan antar kelompok lokasi penelitian, meskipun peran fungsi sumbu 1 dan 2 secara bersamaan atau hanya fungsi sumbu 2 saja tidak berbeda nyata ( $P$ Value 0,590 dan 0,648). Fungsi sumbu 1 dicirikan oleh TDS dan salinitas, sementara fungsi sumbu 2 dicirikan oleh $\mathrm{pH}, \mathrm{DO}$, dan suhu perairan.

\section{BAHASAN}

Pada penelitian awal ini yang dilaksanakan pada musim kemarau terlihat hasil bahwa penyakit karang BBD banyak terjadi pada lokasi yang lebih dekat dengan daratan utama, meskipun pada lokasi terjauh juga masih ditemukan penyakit karang. Dua jenis penyakit karang yang sering ditemukan yaitu BBD (black band disease) dan WS (white syndrome). Kondisi ini dapat menjawab salah satu asumsi bahwa penyakit karang memang banyak ditemukan di lokasi yang dekat dengan daratan utama yang dianggap sebagai pembawa bahan polusi antropogenik. Namun pada lokasi terjau hpun penyakit karang masih ada ditemukan, di mana mestinya polusi antropogenik diasumsikan tidak akan sampai ke lokasi tersebut.

Penyakit BBD merupakan salah satu jenis penyakit dari 4 jenis penyakit yang diketahui berasosiasi dengan perubahan suhu perairan (Kuta \& Richardson, 1996; Bruckner \& Bruckner, 1997), jenis penyakit lain plague (Dustan, 1977; Richardson, 1998), dan jenis 
penyakit yang baru dikenal yaitu penyakit dark spots (Gil- Agudelo \& Garzon- Ferreira, 2001) pada umumnya penyakit tersebut terjadi pada musim panas di saat suhu berada di atas $28^{\circ} \mathrm{C}$ (Kuta \& Richardson, 2002).

Intensitas cahaya dan suhu sangat menentukan keberadaan penyakit karang BBD dan WS, karena lokasi pengamatan berada pada perairan yang dangkal yaitu di daerah reef flat. Kemudian jenis karang juga didominasi oleh karang bentuk pertumbuhan foliose dan encrusting dari genus karang yang sama. Penyakit BBD memiliki bakteri yang berasosiasi dengan cahaya matahari sehingga banyak ditemukan pada karang yang dangkal dengan lebar permukaan koloni karang yang lebih lebar, sehingga lebih efektif menangkap cahaya dan menjadi rumah (host) dari bakteri yang pada akhirnya menimbulkan penyakit.

Pemasukan nutrien (sumber pembuangan kotoran), sedimentasi, dan masuknya air dari daratan merupakan faktor yang potensial mendukung timbulnya kasus penyakit baru (coral disease incidence). Berdasarkan penelitian sudah diperoleh lima faktor (suhu, kedalaman, keragaman karang, dan konsentrasi ortho- fosfat dan nitrit), pengujian secara statistik diperoleh hubungan yang sangat nyata dengan keberadaan BBD (Kuta \& Richardson, 2002). Kemudian Bruckner \& Bruckner (1997) melaporkan bahwa peningkatan terjadinya penyakit BBD pada terumbu karang yang dekat dengan saluran atau daerah pembuangan kotoran dan daerah yang tinggi pemasukkan sedimennya.

Ekosistem terumbu karang merupakan ekosistem yang paling produktif secara biologis, namun juga merupakan ekosistem yang paling sensitif terhadap tekanan (Birkeland, 1997). Terumbu karang Kepulauan Seribu merupakan salah satu contoh ekosistem terumbu karang yang dekat dengan ibukota negara, sehingga kondisi ini sangat berpengaruh terhadap kondisi terumbu karang tersebut. Semakin dekat dengan pantai Jakarta atau berada dalam wilayah Teluk Jakarta akan memiliki kondisi yang lebih buruk dibandingkan dengan terumbu karang yang terletak lebih jauh terutama akibat dampak aktivitas manusia (Cleary et al., 2006).

Pada penelitian ini dapat terlihat bahwa kematian karang akibat penyakit karang akan memberikan dampak pada penurunan keanekaragaman karang terutama jenis Montipora sp. di kawasan tutupan karang tinggi. Semua koloni terinfeksi penyakit karang yang tercatat terutama di kedua pulau Pramuka dan Pari mengalami kematian, kemudian penyakit karang muncul lagi pada koloni baru. Penelitian lain yang dilakukan di beberapa pulau yang dekat dengan daratan utama atau Teluk Jakarta pada tahun 2005 menunjukkan bahwa perairan Onrust sudah tidak ditemukan lagi ekosistem karang hidup (Giyanto et al., 2006). Penurunan kondisi karang juga sudah diketahui dari hasil penelitian sejak tahun 1994 bahwa kekayaan jenis karang perairan Pulau Onrust menurun secara signifikan dalam kurun waktu 64 tahun, dari jenis 96 yang ditemukan pada tahun 1929 menurun menjadi 21 jenis pada tahun 1993. Pulau- pulau lain di Teluk Jakarta diperkirakan mengalami masalah yang sama. Dengan demikian salah satu bagian kawasan Kepulauan Seribu yaitu di Teluk Jakarta sudah tidak bisa lagi dinyatakan sebagai ekosistem terumbu karang, karena beberapa komponen terpenting penyusunan ekosistem sudah hampir tidak lagi ditemukan atau jumlahnya sudah terbatas. Komoditas yang mampu hidup di kawasan ini telah tergantikan dengan komuditas lain dengan dasar lunak (Estradivari et al., 2009).

Dampak polusi antropogenik terhadap salah satu faktor penurunan kondisi terumbu karang didukung oleh pendapat Clearly et al. (2006) yang menyatakan bahwa faktor yang berpengaruh secara nyata pada tutupan karang di Kepulauan Seribu Jakarta adalah gradien lingkungan yang besar, semakin jauh dari Teluk Jakarta maka kondisi terumbu karang akan lebih baik karena jarak mempengaruhi kadar polutan yang masuk ke perairan. Kemudian pernah terjadi ledakan populasi bulu Seribu (Acantaster plancii) di awal tahun 1990- an juga merupakan salah satu contoh gradien lingkungan yang telah menyebabkan terjadi penurunan tutupan karang dari $23 \%$ di 1985 menjadi 17\%di tahun 1995 (DeVantier et al., 1998).

Keberadaan penyakit BBD yang ditemukan banyak pada perairan dangkal (reef flat) di Kepulauan Seribu sesuai dengan penelitian lain yang menemukan BBD di perairan dangkal keberadaannya berbeda nyata dengan lokasi lain. Penelitian yang sama juga menemukan bahwa pada kedalaman lebih dari 6,6 $\mathrm{m}$ tidak ditemukan lagi BBD. Penelitian lain yang mendukung BBD ditemukan berbeda nyata lebih banyak pada kedalaman dangkal di antara- 
nya Rutzler et al. 1983; Taylor, 1983; Antonius, 1985. Pola distribusi pada perairan dangkal ini dikarenakan BBD didominasi oleh cyanobacterium yang tergantung dengan cahaya matahari (photosynthetic cyanobacterium) (Antonius, 1981; Richardson et al., 1997).

Meskipun pada Kepulauan Seribu tidak dilakukan perbandingan suhu antara lokasi yang ada BBD dan daerah yang tidak ada BBD, suatu penelitian telah berhasil melakukan pengukuran perbedaan suhu, di mana suhu perairan pada lokasi yang ada BBD berbeda nyata lebih tinggi dibandingkan dengan lokasi yang tidak ada penyakit. Pada umumnya semua lokasi yang ada BBD memiliki suhu antara $29,0^{\circ} \mathrm{C}-30,0^{\circ} \mathrm{C}$; kecual $\mathrm{i}$ ada satu lokasi ditemukan BBD yang memiliki suhu $26,0^{\circ} \mathrm{C}$.

Khususnya hubungan antara kelimpahan BBD dan tingginya suhu perairan sudah pernah ditemukan oleh beberapa peneliti sebelumnya dari program monitoring secara musiman (Antonius, 1981; Edmunds, 1991; Kuta \& Richardson, 1996; Bruckner \& Bruckner, 1997 Borger \& Steiner, 2005; Voss \& Richardson, 2006; Rodriguez \& Croquer, 2008; Sato et al., 2009; Zvuloni et al., 2009). Intensitas cahaya juga telah disarankan dan menjadi perhatian sebagai faktor lingkungan yang berperan dalam penentuan pola distribusi BBD (Kuta \& Richardson, 2002; Page \&Willis, 2006; Croquer $\&$ Weil, 2009), dan juga perubahan kelimpahan penyakit karang dan perkembangan penyakit pada koloni karang (Sato et al., 2009).

\section{KESIMPULAN DAN SARAN}

\section{Kesimpulan}

Pada penelitian ini dapat disimpulkan beberapa hal di antaranya adalah penyakit karang black band disease (BBD) ditemukan pada setiap lokasi secara spasial di Kepulauan Seribu, kelimpahannya banyak ditemukan pada perairan yang lebih dangkal yaitu rataan termbu (reef plate) dibandingkan dengan lereng terumbu (reef slope). Karang yang banyak terinfeksi adalah jenis karang dari Montipora sp. yang bentuk pertumbuhannya coral foliouse dan coral encrusting. Penyakit karang BBD terjadi pada tutupan karang hidup dalam kelompok kondisi baik di mana tutupan karang hidupnya di atas $50 \%$

Kelimpahan penyakit karang terting i terjadi di Pulau Pramuka Utara $\left(0,15 \mathrm{kol} . \mathrm{m}^{-2}\right)$ Pulau Pari Timur $\left(0,092 \mathrm{kol} . \mathrm{m}^{-2}\right)$, Pulau Penjaliran $\left(0,092 \mathrm{kol} \cdot \mathrm{m}^{-2}\right)$. Kelimpahan penyakit karang terkait dengan peningkatan suhu yang sudah terindikasikan sejak bulan Maret- Juli bersamaan dengan waktu pengambilan data kelimpahan awal.

\section{Saran}

Penelitian penyakit karang masih baru dilakukan di Indonesia sehingga masih banyak bagian-bagian penelitian yang belum dilakukan, di antaranya analisis mikrobiologi penyebab penyakit karang, analisis histologi untuk melihat bagian karang yang diserang atau rusak oleh penyakit dan untuk mengetahui kenapa penyakit karang BBD banyak ditemukan pada karang jenis Montipora sp. dan pada kedalaman dangkal saja.

Penelitian yang sama perlu dilakukan di daerah lain di Indonesia dengan asumsi atau temuan sementara yang diperoleh di Kepulauan Seribu bahwa penyakit karang banyak ditemukan pada kedalaman 0- 1,5 m dan pada karang jenis Montipora sp.

Rekomendasi tindakan pengendalian dan manajemen terhadap dampak penyakit karang terhadap ekosistem terumbu karang secara keseluruhan di Indonesia masih belum dapat diberikan karena membutuhkan data lengkap tentang distribusi dan dampak penyakit karang tersebut di beberapa wilayah di Indonesia.

\section{UCAPAN TERIMA KASIH}

Tulisan ini merupakan bagian dari disertasi saya, yang dalam pelaksanaannya banyak dibantu oleh berbagai pihak. Penulis mengucapkan terima kasih kepada Kementerian Kelautan dan Perikanan yang telah memberikan beasiswa selama studi, dan bantuan dana penelitian dari Pusat Penelitian dan Pengembangan Perikanan Budidaya. Terima kasih juga penulis sampaikan pada semua pihak yang terlibat dalam pengumpulan data di lapangan di antaranya Taman Nasional Kepulauan Seribu, Jakarta, Stasiun Meteorologi Maritim Tanjung Priok, dan Yayasan Terumbu Karang Indonesia. Terima kasih juga disampaikan secara personal yang telah membantu langsung maupun tidak langsung dalam kegiatan penelitian ini meliputi Ali Arman, Agustin Rustam, Muhammad Rasyid, Retia Revanny, dan lainnya.

\section{DAFTAR ACUAN}

Antonius, A. 1973. New observations on coral destruction in reefs. Abs. Assoc. Isl. Mar. Lab. Caribb., 10: 3. 
Antonius, A. 1981. The 'band' diseases in coral reefs. Proc $4^{\text {th }}$ Int. Coral Reef Symp, Manila, 2: 7- 14.

Antonius, A. 1985. Coral diseases in the IndoPacific: a first record. PSZNI: Marine Ecology, 6(3): 197- 218.

Beeden, R., Willis, B.L., Raymundo, L.J., Page, C.A., \& Weil, E. 2008. Underwater cards for assessing coral health on Indo-pacific reefs.

Birkeland, C. 1997. Life and death of coral reefs. (Ed.) Chapman \& Hall, New York, 535 pp.

Borger, J.L. \& Steiner, S.C.C. 2005.The spatial and temporal dynamics of coral diseases in Dominica, West Indies. Bull. Mar. Sci., 77: 137- 154.

BPS DKI Jakarta. 2010. Provinsi DKI Jakarta per Kabupaten/ Kota tahun 2010. http; jakarta. bps.go.id (akses 29 oktober 2013).

Bruckner, A.W. \&Bruckner, R.J. 1997. The persistence of black- band disease in Jamaica: impact on community structure. Proc. $8^{\text {th }}$ Int. Coral Reef Symp., 1:601- 606.

Cleary, D.F.R., Suharsono, \& Hoeksema, B.W. 2006. Coral diversity across a disturbance gradient in the Pulau Serubu reef complex off Jakarta, Indonesia. Biodiversity and Conservation, 15: 3,653- 3,674.

Croquer, A. \& Weil, E. 2009. Changes in Caribbean coral disease prevalence after the 2005 bleaching event. Dis. Aquat. Org., 87: 33- 43.

DeVantier, L., Suharsono, Budianto, A., Tuti, J., Imanto, P., \& Ledesma, R. 1998. Status of coral communities of Pulau Seribu 19851995. Dalam Soemohihardjo, S. (Eds.) Proceeding Coral Reef Evaluation Workshop Pulau Seribu. Jakarta, Indonesia, p. 1- 24.

Ducklow, H.W. \& Mitchell, R. 1979. Observation on naturally and artificially sisease tropical corals: Scanning electron microscope study. Microb. Ecol., 5: 215- 223.

Dustan, P. 1977. Vitality of reef coral populations off Key Largo, Florida: recruitment and mortality. Environ. Geol., 2: 51- 58.

Edmunds, P.J. 1991. Extent and effect of black band disease on a Caribbean reef. Coral Reefs., 10: 161- 165.

English, S., Wilkinson, C., \& Baker, V. 1997. Survey manual for tropical marine resources, $2^{\text {nd }}$ Edn. Australian Institute of Marine Science, Townsville.

Estradivari, E., Setyawan, \& Yusri, S. 2009. Terumbu karang Jakarta: Pengamatan jangka panjang terumbu karang Kepulauan Seribu (2003-2007) (Eds.). Yayasan TERANGI. Jakarta, viii + $102 \mathrm{pp}$.

Frias- Lopez, J., Bonheyo, G.T. , Jin, Q., \& Fouke, B.W. 2003. Cyanobacteria Associated with Coral Black Band Disease in Caribbean and Indo- Pacific Reefs. Applied and Environmental Microbiology, p. 2,409-2,413.

Garret, P. \& Ducklow, H. 1975. Coral diseases in Bermuda. Nature, 523: 349- 350.

Giyanto, Tuti, Y., \& Budiyanto, A. 2006. Analisa Pendahuluan kondisi terumbu karang di Kepulauan Seribu, Jakarta pada tahun 2006. Dalam Tuti, M.I.Y. \& Soemodihardjo, S. (Eds.) Ekosistem terumbu karang di Kepulauan Seribu: monitoring dan evaluasi tiga dasawarsa. LIPI dan Naturalis. Indonesia, p. 9-18.

Gomez, E.D. \&Yap, H.T. 1984. Monitoring reef condition. In Kenchington, R.A. \& Hudson, B.E.T. (Eds.). Coral reef Management Hand Book. Unesco Regional Office for Science and Technology for South East Asia. Jakarta.

Kuta, K.G. \& Richardson, L.L. 2002. Ecological aspects of black band disease of corals: relationships between disease incidence and environmental factors. Coral Reefs, 21 : 393- 398.

Kuta, K.G. \& Richardson, L.L. 1996. Abundance and distribution of black band disease on coral reefs in the northern Florida Keys. Coral Reefs, 15: 219- 223.

NOAA. 2012. Coral reef watch satellite (SST) sea surface temperature anomaly 2009 , 2010, and 2011. http:// coralreefwatch. noaa.gov. [Akses tanggal 12 April 2012]

Page, C. \& Willis, B. 2006. Distribution, host range and large- scale spatial variability in black band disease prevalence on the Great Barrier Reef, Australia. Dis. Aquat. Org., 69: 41- 51.

Ramos- Flores, T. 1983. Lower marine fungus associated with black line disease in star corals (Montastrea annularis, E. \& S. ). Biological Bulletin, 165: 429- 435.

Raymundo, L.J., Courtney, S.C., \& Harvell, C.D. 2008. Coral disease handbook guidelines for assessment, monitoring, and management. Coral reef targeted research and capacity building for management program and its partners, $124 \mathrm{pp}$.

Richardson, L.L. 1996. Horizontal and vertical migration patterns of Phormidium corallyticum and Beggiatoa spp. associ- 
ated with black-band disease of corals. Microb. Ecol., 32: 323- 335.

Richardson, L.L., Kuta, K.G., Schnell, S., \& Carlton, R.G. 1997. Ecology of the black band disease microbial consortium. Proc. $8^{\text {th }}$ Intl. Coral Reef Symp., 1: 597-600.

Richardson, L.L. 1998. Coral diseases: what is really known?. Trends Ecol. Evol. 13: 438443.

Rodriguez, S. \& Croquer, A. 2008. Dynamics of black band disease in a Diploria strigosa population subjected to annual upwelling on the northeastern coast of Venezuela. Coral Reefs, 27: 381- 388.

Ruitzler, K., Santavy, D.L., \& Antonius, A. 1983. The black band disease of Atlantic Reef Coral III. Distribution, ecology, and development. PSZNI Mar. Ecol., 4: 329- 358.

Sato, Y., Bourne, D., \& Willis, B. 2009. Successional changes in bacterial communities during the development of black band dis- ease on the reef coral, Montipora Hispida. The ISME Journal, 4: 203- 214.

Setyawan, E., Yusri, S., \& Timotius, S. 2011. Terumbu Karang Jakarta: Pengamatan Jangka Panjang Terumbu Karang Kepulauan Seribu (2005- 2009) (Eds.) Yayasan TERANGI. Jakarta, Vi+102 pp.

Taylor, B.R. 1983. Assays of microbial nitrogen transformation. In Carpenter, E.J. \& Capon, D.G. (Eds.) Nitrogen in the marine environment. Academic Press. New York, p. 809838.

Voss, J.D. \& Richardson, L.L. 2006. Nutrient enrichment enhances black band disease progression in corals. Coral Reefs, 25: 569576.

Zvuloni, A., Artzy-Randrup, Y., Stone, L., Kramarsky- Winter, E. , Barkan, R., \& Loya, Y. 2009. Spatio- temporal transmission patterns of black- band disease in a coral community. PLoS ONE, 4(4): 1- 10. 